\title{
In-vitro Antimicrobial Resistance of Shigella and Salmonella species Recovered from Abattoir effluent in Afikpo, South Eastern Nigeria
}

\author{
S. C. Onuoha ${ }^{1}$, S.C. Eluu ${ }^{1}$ and M.O. Okata ${ }^{2}$ \\ Department of Biotechnology, Ebonyi State University, PMB 053 Abakaliki, \\ Ebonyi State, Nigeria \\ ${ }^{2}$ Microbiology Unit, Department of Science Laboratory Technology, Akanu Ibiam Federal \\ Polytechnic, PMB 1007 Afikpo, Ebonyi State, Nigeria \\ *Corresponding author
}

\section{Keywords}

Salmonella spp,

Shigella spp,

Antibiotic

resistance,

Abattoir

effluents.

\section{Article Info}

Accepted:

18 March 2016

Available Online:

10 April 2016

\section{A B S T R A C T}

Abattoir effluent has been found to contain high level of contaminants, including disease-causing bacteria such as Salmonella and Shigella species. Antibiotic resistance in these pathogenic bacteria is a serious public health issue. The study was aimed at evaluating the antimicrobial resistance profile of Shigella and Salmonella species isolated from abattoir effluent in Afikpo. Waste water were collected from the two abattoirs, from their point of discharge into surface water bodies with sterile sample bottles and transported to the Laboratory for bacteriological analyses. Bacteria targeted and isolated (Shigella and Salmonella) species were counted characterized and identified using standard microbiological and biochemical techniques. Antibiotic susceptibility study was carried out using Kirby Bauer disc diffusion method according to National Committee for Clinical Laboratory Standards (NCCLS, 2005).The result of the bacterial count showed mean value ranging from $1.00 \times 10^{4} \mathrm{Cfu} / \mathrm{mL}$ to $1.77 \times 10^{4} \mathrm{Cfu} / \mathrm{mL}$. Antibiotic studies showed that Salmonella species had maximum resistance against nitrofurantoin, chloramphenicol, ampicillin and clarithomycin, while in Shigella species maximum resistance was observed in majority of the antibiotics used such as nitrofurantoin, augmentin, perfloxacin, clarithomycin, chloramphenicol and ampicillin.The presence of these multi-drug resistant strains of the isolated organism in abattoir effluents could act as a vehicle to disseminate antibiotic resistance to other bacteria. This emphasizes the need for proper treatment and safe disposal of abattoir effluents in Afikpo.

\section{Introduction}

Abattoir is slaughter house derived from the French word "abattre" meaning "to strike down' (Alonge, 2002). It is a place where animals such as cattle, goats and so on are killed, dressed and distributed for consumption and other industrial purposes. Abattoir operation produces a characteristic highly organic waste with relatively high levels of suspended solid, liquid, and fat. The liquid waste generated is usually composed of dissolved solids, blood, gut content, urine and water. Abattoirs are known all over the world to pollute the environment either directly or indirectly 
from their various processes.Abattoir waste also includes wastewater originating from an abattoir (Adeyemi and Adeyemo, 2007).

In Nigeria, adequate abattoir waste management is lacking in all public abattoirs such that large solid wastes and untreated effluents are common sites (Adeyemo, 2002; Adebowaleet al., 2010) unlike in developed countries where these facilities are adequately provided (Ogbonnaya, 2008). These abattoir wastes could be a source of embarrassment since conventional methods of waste management have been grossly neglected (Adedipe, 2002; Adeyemi \& Adeyemo, 2007).

Abattoir wastes with large quantities of animal feces are often channeled directly into water bodies, used for domestic purposes by human beings. Contamination of river body and land from abattoir wastes could constitute a significant environmental health hazard (Coker et al., 2001; Yaji et al., 2006; Osibanjo et al., 2007). Potential health risks from waterborne pathogens can exist in water contaminated by abattoir effluents (Cadmus et al., 1999).

Wastewater or effluent generated from the abattoir is characterized by the presence of many pathogenic microorganisms, such as Salmonella, Escherichia coli (including serotype 0157:H7), Shigella, parasite eggs and amoebic cysts (Bull and Rogers, 2001; Adebowale et al., 2010) which are of public health importance. Also, several pathogenic bacteria and fungi species has been isolated from abattoir wastewater and surface water; including Staphylococcus, Escherichia coli, Streptococcus, Salmonella, Aspergillus, Mucor, Saccharomyces and Penicillium species (Coker et al., 2001; Adesomoye et al., 2006; Adebowale et al., 2010). These pathogens might threaten public health by migrating into ground water or surface water; wind or vectors like animals, birds and arthropods can transmit diseases from these microorganisms (Gauri, 2004; Raheem and Morenikeji, 2008).

In Nigeria, a number of studies have been done on abattoir waste (Adeyemo, Ayodeji \& Aika-Raji, 2002; Nwanta, Onunkwo \& Ezenduka, 2010; Nafarda et al., 2012e.t.c, and it was found that several bacteria such as, Escherichia coli 0157:H7, Salmonella spp, Shigella spp and Campylobacter spp. were present in the waste. Also, several studies in Africa have been done by different researchers on abattoir wastes and different pathogenic bacteria were recovered from untreated abattoir wastewaters (BenkaCoker \&Ojior 1995; Abiade-Paul et al. 2005; Nyamboya, Okemo, \&Ombori, 2013).

The contribution of abattoirs and associated wastewaters is rarely considered and yet abattoirs are potential sources of enteric bacteria that could possess antibiotic resistance genes. No data have been reported from the study area, hence the study was designed to isolate and determine the antimicrobial resistance of the target bacterial isolates in abattoir wastewaters in Afikpo.

\section{Materials and Methods}

\section{Study Area}

The study was conducted in Afikpo. Afikpo, also known as "Ehugbo" is a town and the second largest urban area in Ebonyi State, Nigeria. It is the headquarters of Afikpo North Local Government Area. It is situated in the Southern part of Ebonyi State and is bordered to the North by the town of Akpoha, to the South by Unwana, to the South West by Edda in Afikpo South L.G.A., to the East by the Cross River and to the West by Amasiri. Afikpo spans an area 
approximately 164 square kilometers in size. It lies on latitude $5.89^{\circ} \mathrm{N}$ and longitude $7.94^{\circ} \mathrm{E}$ and it has a population of 71,866 .

\section{Sample Collection}

A total of twenty (20) abattoir effluents used in this research work were collected aseptically with the aid of a sterilized sample container, in the morning during the peak activities between 8:00am and 9:00am from two different abattoirs in Afikpo, "private" and "public" abattoir serving the meat protein (beef) needs of about $55 \%$ of the populace. Samples were collected from the point where it is discharged to the environment without treatment, and were transported to Microbiology Laboratory unit of Akanu Ibiam Federal Polytechnic, Unwana. Processing of the samples for the isolation of bacteria was carried out within 24 hours of sample collection.

\section{Isolation, Identification and Characterization of the Isolates}

Isolation and identification of isolates from the abattoir effluent samples were aseptically carried out using standard microbiology techniques as described by Cheesbrough, 2006. The abattoir effluent samples were aseptically inoculated onto culture media namely Salmonella-Shigella agar. The agar plates were incubated at $37^{\circ} \mathrm{C}$ for 18-24 hours. All the bacterial isolates were identified based on their colony morphology, Gram's reaction, catalase test, motility test and biochemical tests such as oxidase test, citrate test, indole test, Methylred-Voges Proskauer (MRVP) test, urease test, hydrogen sulphide production test, and sugar fermentation

\section{Antibiotic Susceptibility Test}

Salmonella and Shigella isolates were subjected to in-vitro susceptibility test against commonly used antimicrobial agents using disk diffusion method following guidelines established by the Clinical and Laboratory Standards Institute (CLSI). In brief, by taking pure isolated colony, bacterial suspension was adjusted to $0.5 \mathrm{McF}$ arland turbidity standards. The diluted bacterial suspension was then transferred to Mueller-Hinton agar plate using a sterile cotton swab and the plate was seeded uniformly by rubbing the swab against the entire agar surface followed by $24 \mathrm{~h}$ incubation. After the inoculums were dried, antibiotic impregnated disks were applied to the surface of the inoculated plates using sterile forceps. The plates were then incubated aerobically at $37{ }^{\circ} \mathrm{C}$ for $24 \mathrm{~h}$. Finally, the zone of inhibition was measured including the disk diameter. The susceptible, intermediate and resistant categories were assigned on the basis of the critical points recommended by the CLSI and according to the manufacturer's leaflet attached to the disks. Antimicrobials used for susceptibility testing of Salmonella and Shigella species were; Nitrofurantion, Ciprofloaxcin, Cetriaxone, Gentamican, Ofloxacin, Augumentin, Pefloxacin, Clarithomycin, Chloramphenicol and Ampicillin

\section{Results and Discussion}

The total bacterial counts $(\mathrm{Cfu} / \mathrm{ml})$ of abattoir effluents from both private and public abattoirs is shown in (figure. 1). It ranged from $1.00 \times 10^{4} \mathrm{Cfu} / \mathrm{ml}$ to $1.77 \times 10^{4}$ $\mathrm{Cfu} / \mathrm{ml}$. The highest count was obtained from public abattoir, while the least count was obtained from private abattoir (Figure 1). These figures indicated very high microbial loads and can be attributed to the poor sanitary and hygienic practices of the abattoirs' management and workers, the poor state of health of the slaughtered cows 
and faecal contamination from the intestines of the slaughtered animals.

In this study, Salmonella and Shigella species were isolated and identified in 20 abattoir effluent samples collected from both private and public abattoir. Fifty bacterial isolates were obtained from the 20 abattoir effluent samples collected. Out of the 50 bacterial isolates obtained, 32(64\%) were Salmonella spp, while 18(36 \%) were Shigella $\operatorname{spp}($ Table 1). Some of the samples collected from private and public abattoir were positive for both Salmonella and Shigella species

The result of the antibiogram ofthe isolates is shown in (Figure. 2). The result revealed that Shigella specie was resistant to Nitrofurantoin, Augumentin, Pefloxacin, Clarithomycin, Chloramphenicol and Ampicillin. But was sensitive to the rest of the antibiotics used with the following zones of inhibition in millimeters: Ciprofloxacin, $20 \mathrm{~mm}$, Cetriaxone, $11 \mathrm{~mm}$, Gentamicin, 12 $\mathrm{mm}$, and Ofloxacin, $15 \mathrm{~mm}$, While Salmonella was resistant to Nitrofurantoin, Clarithomycin, Chloramphenicol and Ampicillin (AMP). But was sensitive to the rest of the antibiotics used with the following zones of inhibition in millimeter: Ciprofloxacin, $10 \mathrm{~mm}$, Gentamicin, $20 \mathrm{~mm}$, Cetriaxone, $12 \mathrm{~mm}$, Ofloxacin, $20 \mathrm{~mm}$, Augumentin, $11 \mathrm{~mm}$ and Pefloxacin, $20 \mathrm{~mm}$ (Figure 2).

The total bacterial counts of abattoir effluents from both private and public abattoirs in Afikpo during the study period as illustrated in (Figure.1) indicates very high microbial loads not in compliance with WHO guidelines. The abattoir effluents were not treated and are being washed out into the drainage channel during and after slaughter .Such contamination constitute a hazard to public health since it could spread to water sources and make such water unfit for human consumption and even transmit disease. As presented in a similar study by Ogunseitan (2002), the high bacterial loads could be attributed to the poor sanitary and hygiene practices of the abattoirs' management and workers, the poor state of health of the slaughtered cows and faecal contamination from the intestines of the slaughtered animals. As observed in the study location, wastewater from the slaughtering and dressing slabs in both abattoirs is washed into open drainage without any form of treatment and could eventually percolate into surrounding surface and ground waters. Abiola (2004), in his work contended that water and leachates from series of decomposition processes from abattoir wastes percolates into surrounding surface water bodies and poses danger to those working in the abattoirs and those living around them as available water sources close to them becomes contaminated. Added to this danger is the possibility of recontamination of meat products when such polluted water is used for processing in the same abattoir.

Values obtained for the bacteriological count also show that the TBC for public abattoir are relatively high compared to those of private abattoir. This could be attributed to the fact that on the average, more animals are slaughtered in public abattoir daily as compared to that of private abattoir. We inferred from the study that the higher the number of cows slaughtered (in the light of currently poor manufacturing and hygienic practices), the higher the microbial load and thus, the greater the risks of contamination of surrounding water bodies and also of meat to be sold to the public.

The present study revealed the presence of Salmonella in majority of the samples analysed from both abattoirs with prevalence rate of $64 \%$. This finding, in 
itself, is not surprising since Salmonella is reported to be an environmentally persistent pathogen capable of surviving and proliferating in diverse environments (Winfield and Groisman, 2003). Moreover, previous studies report that Salmonella can persist in the farm environment for extended periods of time due to movement within the farm from animals, human and livestock excrement, soil and plants (Kupriyanov et al., 2010). The 64\% prevalence of Salmonella obtained in our study is however; higher than the $33.3 \%$ prevalence rate by Iroha et al., 2016; $19.5 \%$ by Bagudo et al., 2014; $13.5 \%$ by Santos et al., 2001. Nafarda et al., 2006 obtained 12.3\% from receiving water bodies and $13.2 \%$ from vegetables irrigated with wastewaters from Gwagwalada abattoir, Nigeria.

The higher prevalence in this study could be as a result of the poor sanitary and hygiene practices of the abattoirs' management and workers, the poor state of health of the slaughtered cows and fecal contamination from the intestines of the slaughtered animals. As observed in the study location, the entire environment of the abattoir are filled with fecal materials from the animals that are being slaughtered and also contamination from the wastewater from the slaughtering and dressing slabs in both abattoirs is washed into open drainage without any form of treatment. Therefore the presence of Salmonellae in the abattoir wastewaters however is of public health concern. Center for disease control and prevention (CDC) reported Salmonella as the most prevalent bacterial diarrheal pathogen followed by Shigella sp., Camphylobacter sp. and E. coli. Wedel et al. (2005) reported that cattle are the reservoir of Salmonellae that may be transmitted to humans with resultant illness. The present study equally revealed the presence of Shigella sp in all the samples analysed from both abattoirs with prevalence rate of $34 \%$. The presence of Shigella in the abattoir waste is an indication that the contamination is of human origin. Humans are the only natural host for Shigella and infection occurs by ingestion. It is reasonable to suggest that the slaughter waste was not the source of the Shigellasince Shigella spp. are bacteria with humans and primates as hosts (Strockbine \& Maurelli 2005). More likely the source is fecal contamination from humans indicating that abattoir workers or other people resident at the abattoir area defecate into the drainage channel.

The emergence of antimicrobial resistant bacteria increases in environment where antimicrobials are indiscriminately used in the public. In Nigeria and other developing countries, acquired bacterial resistance to antimicrobial agents as obtained in this study is common and the complex socioeconomic and behavioral factors associated with this phenomenon include abuse of antibiotics among other complex factor. In this study all the isolates were resistant to two or more antibiotics. The two isolates Shigella and Salmonella species were both resistant to Nitrofurantoin, Clarithomycin, Chloramphericol and Ampicillin, but was sensitive to Ciprofloxacin, Cetriaxone, Gentamicin, and Ofloxacin. The high resistance observed to the antimicrobial could be due to uncontrolled availability of this antimicrobial agents in drug vendors, which leads to misuse. Thus, this might exert greater selection pressure for the resistant strains thereby making them resistant to antimicrobials. Multiple bacterial resistances to drugs had earlier been reported in aquaculture environments by other workers across the globe (Hartha et al., 2005). Puah et al (2013) had reported up to six different resistance pattern and resistance to (two or more drugs) in $93 \%$ of tested isolates. 
Table.1 Distribution of Bacterial Isolates at the Private and Public Abattoir in Afikpo

\begin{tabular}{|l|c|cc|c|l|}
\hline Bacterial isolates & $\begin{array}{c}\text { Private abattoir } \\
\mathrm{n}=10\end{array}$ & $\begin{array}{c}\text { Public abattoir } \\
\mathrm{n}=10\end{array}$ & $\begin{array}{c}\text { Total }(\%) \\
\mathrm{n}=20\end{array}$ & $(\mathbf{n}=\mathbf{5})$ & $\begin{array}{l}\text { Total (\%) } \\
(\mathbf{n = 2 0})\end{array}$ \\
\hline Salmonella $\mathrm{spp}$ & 12 & 20 & $32(64 \%)$ & 5 & $20(33.3 \%)$ \\
\hline Shigella spp & 8 & 10 & $18(36 \%)$ & 5 & $20(33.3 \%)$ \\
\hline
\end{tabular}

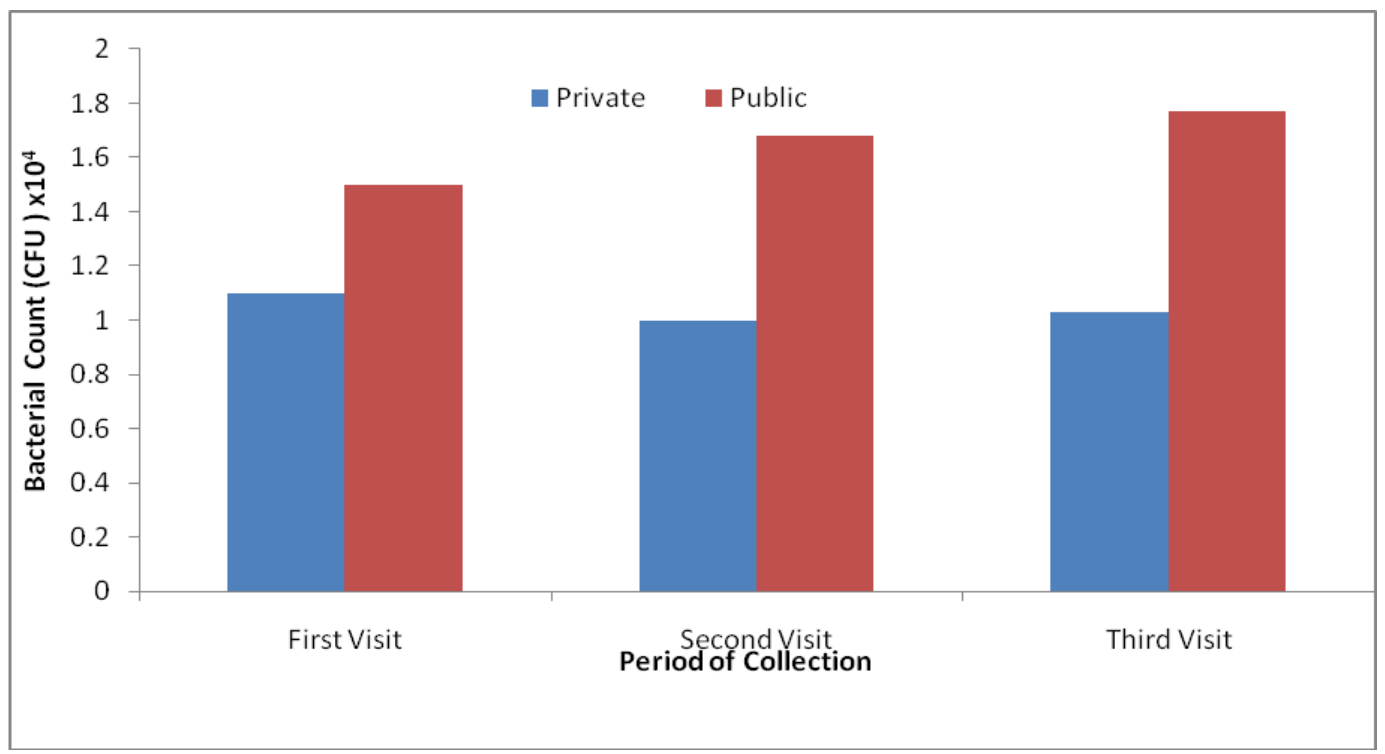

Figure.1 Total Bacterial Count (CFU) of Wastewater Samples from Private and Public Abattoir

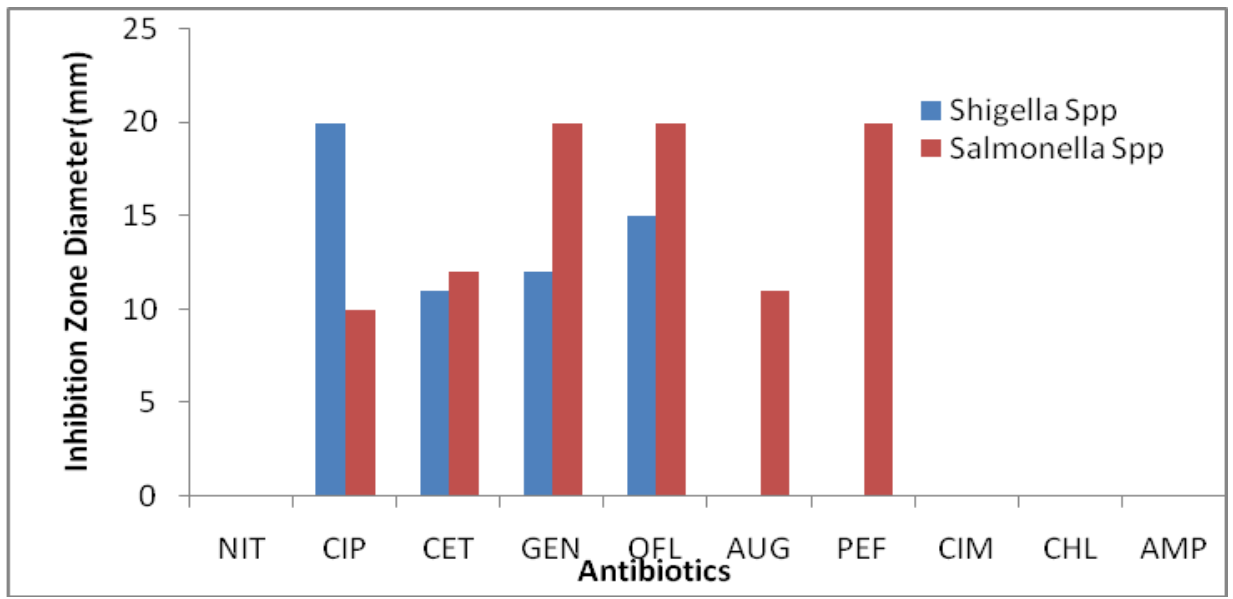

Figure.2 Antibiotics Susceptibility Pattern of Salmonella and Shigella Spp from Abattoir Wastewaters

Resistance to multiple antibiotics can lead to occurrence of newly emerging resistant bacteria which may be transmitted to consumers causing infection that are difficult to treat.
The relatively high resistance of bacterial pathogen to antibiotics in this study agrees with the findings of Koesak et al., (2012) who had previously detected bacterial resistance against ampicillin, gentamicin, 
erythromycin, tetracycline and ciprofloxacin at different times. Also the prevalence of intrinsic multi-resistance to common antimicrobial has been documented (Wright, 2007; Balz, 2008., Brown \& Balkwill, 2009; Cox \& Wright, 2013).

The presence of antimicrobial resistance have the potential to adversely affect human health by causing illness that is more difficult to treat because of the resistance profile of the microorganism.

The fact that antimicrobial resistant genes are common in environment (Riesenfeld et al., 2004) and play an important role for bacterial survival, the high prevalence of multidrug resistance bacteria in abattoir effluent is probably due to a multitude of biological as well as ecological factors. The fact that these organisms are multi-drug resistant implies that there is possibility of these bacteria to habor plasmids with several genes conferring resistance to abroad array of antibiotics. This suggest that there is high chance of spreading these pathogen and the associated resistant genes to humans and animals.

In conclusion, the research has described the bacterial profile and antimicrobial resistance pattern of Shigella and Salmonella species from abattoir effluents in Afikpo.On-site observation of the two (2) abattoirs shows that the sanitary conditions under which carcasses are being dressed are far from ideal. That is, the condition of the butcher shop, utensils used and personal hygiene were not up to the recommended standards. Also, this study observed that untreated abattoir wastewater discharged into water bodies in Afikpo, contains antibiotic resistant bacteria that could impact on public health. The importance of adopting appropriate abattoir wastewater treatment measures to prevent the chances of contaminating water bodies and ground water is therefore recommended.

\section{References}

Abiade-Paul, C., Kene, I. \&Chah, K., 2005. Occurrence and antibiogram of Salmonellae in effluentfrom Nsukka Municipal abattoir.Nig. Vet. Journal, 27(1), pp.48-53.

Abiola, S. S. (2004)“Assessment of abattoir and slaughter slab operation in Oyo state" Nig. J. of Animal Product, 5:54-62.

Adebowale, OO; Alonge, DO; Agbede, SA and Adeyemo,

(2010).Bacteriological assessment of quality of water used at the Bodija municipal abattoir, Ibadan, Nigeria.Sahel J. Vet.Sci. 9(2): 63-67.

Adedipe, NO (2002). The challenge of urban solid waste management in Africa, in: H. Baijnath and Y. Singh (Eds) Rebirth of Science in Africa (Hatfield, South Africa: Umdaus Press), pp. 175-192.

Adesemoye, A.O., Opere, B.O. and Makinde, S.C.O. (2006). Microbial content of abattoir waste water and its contaminated soil in Lagos, Nigeria. Afr. J. Biotechnol. 5(20): 1963-1968.

Adeyemi, I.G. and Adeyemo, O.K. (2007).Waste management practices at the Bodijaabattoir, Nigeria. Int. J. Environ. Stud. 64:71-82.

Adeyemo, O. K., (2003). Consequences of pollution and degradation of Nigerian aquatic environment on fisheries resource. The Environmentalist, 23: 297 -306.

Adeyemo, O.K., Ayodeji, I.O. and AikiRaji, C.O. (2002). The water quality and sanitary conditions in a major abattoir (Bodija) in Ibadan, Nigeria.Afr. J.Biomed. Res.5: 51-55. 
Adeyemo, OK (2002). Unhygienic operation of a city abattoir in Southwestern Nigeria: Environmental implication. African J. Env.Asses.andManag, 4(1): 23-28

Akinyemi, K.O., Smith, S.I., Oyefolu, A.O., Coker, A.O., 2005. Multidrug resistance

Salmonellaentericaserovartyphi isolated from patients with typhoid fever complications in Lagos, Nigeria. Public Health, 119: 321327.

Alonge, D. O. (2002). Textbook of meat hygiene in the tropics, FarmcoePress, Ibadan, 2: 5860.

Bagudo, A.I., Tambuwal, F.M., Faleke, O.O., Egwu, O.O., Aliero, A.A., 2014. Prevalenceof Salmonella serotypes in Sokoto abattoir effluents and vegetables cultivated around the abattoir.Microbiol. Res. Int. 2 (2), 13-17.

Baltz, R.H (2008). Renaissance in antibacterial discovery from actinomycetes.Curr.Opi.Pharmacol. 8:557-563.

Benka-Coker, M. \&Ojior, O., 1995. Effect of slaughterhouse wastes on the water quality of Ikpoba River, Nigeria. Bio.Technology, 52, pp.512.

Brown, M.G \&Balkwill, D.L (2009). Antibiotic resistance in bacteria isolated from the deep terrestrial subsurface, Microbial Ecol, 57:484493.

Bull,Wand Roger, S.S (2001). Microbial properties of abattoir effluent. Oxford,London Publishing Coop. Pp 14.

Cadmus, S. I. B., Olugasa, B. O., and Ogundipe, G. A. T. (2004). "The prevalence and zoonotic importance of bovine truberculosis in Ibadan", in proceedings of the $37^{\text {th }}$ Animal
Congress of the Nigerian Veteriniary Medical Association, 2: 65 - 70.

Cheesbrough, M (2006). District laboratory practice in tropical countries, Microbiological tests. Chapter 7.In: Cheesbrough M, Ed. pt 2. 2nd Ed. Cambridge: Cambridge University Press. pp: 9-267

Clinical Laboratory Standards Institute (CLSI) (2005). Performance Standards For Antimicrobial Disc Susceptibility Test; 8th ed. Approved Standards, m2A8, Wayne, $\mathrm{Pa}$ (USA).11:64-68.

Coker, A.O, Olugasa, B.O and Adeyemi, A. $\mathrm{O}(2001)$. Abattoir waste water quality inSouthwestern Nigeria.Proceedings of the 27th WEDC conference, Lusaka,Zambia.Loughborough University press, United Kingdom.329-331.

Cox, G \& Wright, G.D (2013). Intrinsic antibiotic resistance:mechanisms, origin, challenges and solutions, Int J. MedMicrobiol, 303: 287-292.

Gauri, S. M (2004).Characterization of effluent waste water from abattoirs for land applications, Food Reviews International, 20(3): 229-256.

Hatha, M., Viverkanandam, A.A., Joice, G.J \&Chistol< G.J (2005). Antibiotic resstance patterns of mobile aeromonds from raised fresh fish, Int. J. Food Microbiol, 98 : 131-134.

Iroha, I.R., Eromonsele, O.B., Moses, I.B., Afiukwa, F.N.,Nwakaeze, A.E and Ejikeugwu, P.C (2016). In-vitro antibiogram of multi-drug resistant bacteria isolated from Ogbete abattoir effluent in Enugu State, Nigeria, Int. Res. J Pub., health, 3(1):1-6.

Koesak, D., Borek, A.,Daniluk, S., Grabowska, A \& Pappelbaum, K (2012). Antimicrobial susceptibility 
of Listeria monocytogenes strains isolated food and food processing environment in Poland, Int. J. Food Microbiol, 158: 203- 208.

Kupriyanov, A.A., Semenov, A.M and van Bruggen, A.H.C., 2010. Transition ofenteropathogenic and saprophytic bacteria in the niche cycle animalsexcrement-soil-plants-animals.Biol. Bull. 37,263-267

Manson, C.F. (1991). Biology of FreshwaterPollution.2nd ed. Longman Scientific andTechnical John Witey and sons, Inc. New York, P. 351.

Meadows, R. (1995). Livestock legacy: Environ. Health Perspect. 103(12): 1096-1100.

Nafaranda, W.D, Yaji, A and Kubkomawa, H.I, (2006). Impact of abattoir wastes on aquatic life: A case study of Yola abattoir. Global $J$ Pure ApplSci, 12:31-33.

Nafarnda, W. D., Ajayi, I. E., Shawulu, J. C., Kawe, M. S., Omeiza, G. K., Sani, N. A., Tenuche, O.Z., Dantong, D. D. \& Tags, S. Z., 2012. Bacteriological Quality of Abattoir Effluents Discharged into Water Bodies in Abuja, Nigeria. ISRN Veterinary Science, 2012, pp.15.

Nwanta, J.A., Onunkwo, J. and Ezenduka, E. (2010). Analysis of Nsukka metropolitan abattoir solid waste and its bacterial contents in south eastern Nigeria: public health implication. Archenviron \& Occup. health, 65(1): 21-26.

Nyamboya, R.A., Okemo, P.O \& Ombori, O. (2013). Isolation of High Antibiotic Resistant FecalBacteria Indicators, Salmonella and Vibrio Species from Raw Abattoirs Sewage in Peri-Urban Locations of Nairobi, Kenya. Greener J.BiolSci3(5):172178.
Ogbonnaya, C. (2008). "Analysis of groundwater pollution from abattoir waste in Minna, Nigeria". Res. J. Dairy Sci, 2(4): 74-77.

Ogunseitan, O.A (2002). Caffeine-induced enzyme activity in Pseudomonas putidaATCC 700097.World J. Microbiol.Biotechnol.18: 423-428

Osibanjo, O and Adie, G.U (2007).Impact of effluent from Bodija abattoir on the physicochemical parameters of Oshunkaye stream in Ibadan City, Nigeria. Afri. J. Biotechnol., 6(6915):10806-1811

Puah, S., Puthucheary, S.D., Liew, F and Chua, K( 2013). Aeromonas aquariorum clinical isolates: antimicrobial profile, plasmids and genetic determinants. Int. J.Antimicrobial Agents, 41: 281-284.

Raheem, N K and Morenikeji, O A (2008).Impact of abattoir effluents on surface waters of the Alamuyo stream in Ibadan.J Appl. Sci. Environ Manag. 12 (1): 73-77

Santos, R.L, Zhang, S, Tsolis, R.M, Kingsley, R.A, Adams ,L.G and Baumler, A.J (2001). Animal models of Salmonella infections: enteritis versus typhoid fever. Microb Infect, 3(14-15):1335-1344.

Strockbine, N.A. \&Maurelli, A.T., 2005.P. 811. In: Brenner, D. J., Krieg, N. R., \& Staley, J. T. (ed.), Bergey's manual of systematic bacteriology, 2nd ed., vol. 2. The Proteobacteria. Springer-Verlag, New York, NY.

Wedel, S.D, Bender, JB, Leano FT, Boxrud DJ, Hedberg $\mathrm{C}$ and Smith, K.E(2005). Antimicrobial drug susceptibility of human and animal Salmonella typhimurium, Minnesota, 1997-2003.Emerg. Infect Dis, 11:1899-1906.

Winfield, M.D and Groisman, E.A., 2003. Role of non host environments in the 
lifestyles of Salmonella and Escherichiacoli.Appl. Environ. Microb. 69, 3687-3694.

Wright,G.D (2007). The antibiotic resistome: the nexus chemical and genetic diversity. Nat Rev. Microbiology, 5:175-186
Yaji, A, Nafarnda, W. D and Kubkomawa, H. I (2006)." "Impact of abattoir waste on aquatic life: a case study of Yola abattoir, Global J. Pure Appl. Sci., 12: $31-33$.

\section{How to cite this article:}

Onuoha, S. C., S.C. Eluu and Okata, M.O. 2016. In-vitro Antimicrobial Resistance of Shigella and Salmonella species Recovered from Abattoir effluent in Afikpo, South Eastern Nigeria. Int.J.Curr.Microbiol.App.Sci. 5(4): 488-497. doi: http://dx.doi.org/10.20546/ijcmas.2016.504.058 